\title{
Impact of Mulching Material on the Growth, Yield and Quality of Watermelon (Citrullus lonatus)
}

\author{
S. Dadheech*, Ramawtar and C.M. Yadav
}

College of Agriculture, Bhilwara, Maharana Pratap University of Agriculture \& Technology, Udaipur (Raj.), India

*Corresponding author

\section{A B S T R A C T}

\section{Keywords}

Watermelon, Mulch, Growth and yield parameter

Article Info

Accepted:

20 June 2018

Available Online:

10 July 2018
The field experiment was conducted on watermelon (Citrulluslonatus thumb) cv. sugar baby at Krishi Vigyan Kendra, Bhilwara, MPUAT, Udaipur during summer season of 2014 to study the impact of mulching material on the growth, yield and quality of watermelon cv. sugar baby in randomized block design (R.B.D.) in three replications. All the plant growth, yield and quality characters were superior with silver mulch while plants without mulch (control) resulted poor growth and yield. With economic point of view, silver mulch resulted in the highest net return and found to be more economical with highest cost: benefit ratio.

\section{Introduction}

Vegetable crop production is on the increase all over the world both in urban, peri-urban and rural areas. Water melon (Citrullus lonatus thumb) is one important cucurbits vegetables crop grown extensively in India and in tropical and sub-tropical countries of the world. India has favorable ecological condition for enough production of vegetable for growing human population but the resource poor farmers are facing serious problems of price fluctuation, inclement weather condition such as dry spell, moisture shortage, high temperature and solar radiation regimes, glut due to poor storage conditions, biotic and abiotic stresses, pest incidence and physiological disorder, all of which affect vegetable crop production in India. In view of this, some cultural practices such as mulching is used to regulate the soil temp, moisture content, weeds, pest and disease control. It is known that plant development and yield increases occur with balance of soil temperature which there are differences between night and day time temperature, in which mulching play great role to increase yields, promote early harvest, reduce fruit defects, reduce evaporation from the soil surface, prevent weed growth, modify soil temperature and reduce insect number in vegetable production (Splilittstoesser, 1990), the effective of which depends on the type of mulching material used. 
Development of new technologies and especially application of polyethylene film as mulch have enhanced yield (Brinen, 1979). The greatest benefit from plastic mulch is that the soil temperature in the planting bed is raised, promoting faster crop development and earlier harvest. Black plastic mulch can give a harvest earlier by some 7-14 days, while clear plastic may advance the harvest date by 21 days. Soil water loss is reduced under plastic mulch. As a result, more uniform soil moisture is maintained and irrigation frequency can be reduced. The growth of plants on mulch can be twice that of plants in un-mulched soil. Because larger plants will require more water, mulching is not a substitute for irrigation. Black and white on black mulches will reduce light penetration to the soil. Weeds cannot generally survive under such mulch. Fertilizer beneath the mulch is not lost by leaching so that fertilizers are optimally used and not wasted. The soil under plastic mulch remains loose, friable and well aerated. Roots have access to adequate oxygen and microbial activity is enhanced. Soil mulching with plastic film is very beneficial because cucurbits, watermelon being one of them are very shallow rooting and do not like being hoed (Messiaen, 1992). Plastic mulch has been reported to increase watermelon stem growth early and total yield (Bhella, 1988). The effect of mulch color on crop yield has been studied on several crops including tomato and pumpkin (White, 2002).

Therefore, considering the importance of different mulching in various vegetable crops, the present investigation was carried out to study the effect of different mulching material on growth, yield and quality of watermelon.

\section{Materials and Methods}

The field experiment was conducted on watermelon belongs to cucurbitaceae family cv. sugar baby at Krishi Vigyan Kendra, Bhilwara (MPUAT, Udaipur) Soils of the experimental site are classified as sandy loam soil. The annual rainfall in the region is about $600 \mathrm{~mm}$. The experiment was laid out in randomized block design with three replications. There were total eight treatment of mulching materials viz. Control $\left(\mathrm{T}_{1}\right)$, Wheat Straw $\left(\mathrm{T}_{2}\right)$, Grasses $\left(\mathrm{T}_{3}\right)$, Black Mulch $\left(\mathrm{T}_{4}\right)$, Silver Mulch $\left(\mathrm{T}_{5}\right)$, Red Mulch $\left(\mathrm{T}_{6}\right)$, Blue Mulch $\left(\mathrm{T}_{7}\right)$ and Yellow Mulch $\left(\mathrm{T}_{8}\right)$.

Plant growth beds were prepared $1.5 \mathrm{~m}$ apart from each other. Different color polyethylene mulches were laid down on the beds and holes were opened at $1 \mathrm{~m} \times 1 \mathrm{~m}$ for planting the seedlings. Thirty days old seedlings prepared in protrays were transplanted in the first week of January in experimental plots. The required cultural practices were made during the growing period. Mulching applied upto $50 \mathrm{~cm}$ both the side from the stem of watermelon. Temperature and moisture content will be carried out at $10 \mathrm{~cm}$ and $15 \mathrm{~cm}$ depth. The thickness of all polyethylene mulch was 30 microns While Grasses and Wheat Straw was applied at 6 inch thick. The fertilizers were applied @ 100:50:50 NPK kg/ha. Full dose of $\mathrm{P}_{2} \mathrm{O}_{5}$ and $\mathrm{K}_{2} \mathrm{O}$ was applied as basal dose and nitrogen was given in two equal split as basal and top dressing at 30 DAS. The farm yard @ 20 tons per hectare was mixed in soil uniformly to all the treatments. Water soluble fertilizer such as 19:19:19 were also applied.

Five plants were randomly selected from each experimental plot for recording observations on growth, flowering, yield and quality parameter and subjected to statistical analysis of variance technique as described by Panse and Sukhatme (1985).

\section{Results and Discussion}

\section{Effect on growth and yield}

The result showed that different types of mulching material significantly influenced the growth parameters of watermelon viz- number 
of branches per vine, main vine length and number of nodes per vine over control. Among different mulching treatments, treatment $\left(T_{5}\right)$ silver mulch resulted higher number of branches per vine, increased main vine length and number of nodes per vine. However, control recorded the minimum growth. The increase in growth parameters was attributed to sufficient soil moisture near root zone and minimized the evaporation loss due to mulching. The extended retention of moisture and availability of moisture also leading to higher uptake of nutrient for proper growth and development of plants, resulted higher growth of plant as compared to control. The changes in soil temperature below plastic mulch could be attributed to different manners of heating and heat transfer to soil and also to heat accumulation during day and loss during night. Similar findings have also been obtained by Deanban et al., (2004), Ansary and Roy (2005) in watermelon, Al Majali and Kasrawi (1995) in muskmelon and Alemayehu-Ambaye and Joseph (2002) in melon (Table 1).

The result indicated that the effect of different mulching material on fruit length of watermelon was significantly increased than control. Maximum fruit length was observed in treatment silver mulch, whereas the minimum fruit length of watermelon was noted in control. The highest fruit length under silver mulch was due to congenial soil moisture result higher uptake of nutrition for better growth of fruit and the reduction in evaporation losses of soil moisture caused by mulches covered the soil surface in row of watermelon. The above results were in consonance with those of Johnson et.al. (2000), Ansary and Roy (2005) in watermelon and Sharma and Agarwal Narendra (2004) in tomato and Suresh and Ashok Kumar (2006) in pointed gourd.

Silver polyethylene mulch was found to have significantly better effect on the extent of fruit set than other mulching material tried. This mulch consistently increased higher fruit set than other mulch and no mulch. This might have been influenced by favorable soil temperature, moisture conditions and pest disease control as influenced by silver mulch.

The present finding was in accordance with Andino and Motsenbocker (1998), Johnson et al., (2001), Ansary and Roy (2005) in watermelon and Hanna (2000) in cucumber.

It was found that all treatments of mulching material were significantly increased the average fruit weight $(\mathrm{kg})$ of watermelon than control. Among all mulching treatments, maximum average fruit weight was recorded in treatments silver mulch.

It appears that silver mulch might have induced favorable conditions conducive to attainment of fruits with higher weight. The above resultswere in agreement with those of Ansary and Roy (2005), Arancibia and Motsenbocker (2008) in water melon and Angrej Ali and Gaur (2007) in strawberry.

It was found that all the treatment of mulching material was significantly increased the fruit yield of watermelon. Among all mulching treatments, maximum fruit yield recorded in treatment silver mulch which was higher as compare to other mulch and no mulch.

Plants under polyethylene (Silver mulch) produced larger fruit and have higher fruit yield per vine because of better plant growth due to favorable hydrothermal regime of soil and complete weed free environment.

The above results were in consonance with those of Qadir (1992), Al-Majali and Kasrawi (1995), Johanson et al., (2000) and Ansary and Roy (2005) and Cenobio et al., (2007) in watermelon. Ibarra et al., (2001) in musk melon (Table 2). 
Table.1 Effect of different mulching materials on growth and yield of watermelon cv. Sugar baby

\begin{tabular}{|c|c|c|c|c|c|c|c|c|c|c|}
\hline \multirow[t]{2}{*}{ Treatment } & \multirow{2}{*}{$\begin{array}{c}\text { No. of } \\
\text { branches/ } \\
\text { vine }\end{array}$} & \multicolumn{2}{|c|}{ Vine length $(\mathrm{cm})$} & \multirow{2}{*}{$\begin{array}{l}\text { No. of } \\
\text { Node }\end{array}$} & \multirow{2}{*}{$\begin{array}{l}\mathrm{M} / \mathrm{F} \\
(\mathrm{Sex}) \\
\text { Ratio }\end{array}$} & \multirow{2}{*}{$\begin{array}{l}\text { Fruit } \\
\text { Length } \\
(\mathrm{cm})\end{array}$} & \multirow{2}{*}{$\begin{array}{l}\text { Fruit } \\
\text { girth } \\
(\mathrm{cm})\end{array}$} & \multirow{2}{*}{$\begin{array}{c}\text { No. of } \\
\text { Fruit/ } \\
\text { Vine }\end{array}$} & \multirow{2}{*}{$\begin{array}{c}\text { Fruit } \\
\text { Wt. } \\
(\mathrm{kg})\end{array}$} & \multirow{2}{*}{$\begin{array}{l}\text { Fruit } \\
\text { Yield } \\
\text { T/ha }\end{array}$} \\
\hline & & 45 DAS & Harvest & & & & & & & \\
\hline Control & 7.40 & 104.56 & 158.67 & 41.78 & 5.97 & 27.03 & 14.59 & 2.17 & 2.80 & 21.59 \\
\hline Wheat Straw & 11.07 & 111.68 & 184.26 & 43.33 & 5.43 & 29.01 & 15.32 & 2.24 & 2.83 & 21.37 \\
\hline Grasses & 10.67 & 117.14 & 185.67 & 44.62 & 5.07 & 29.14 & 15.07 & 2.30 & 2.97 & 24.56 \\
\hline Black Mulch & 13.63 & 132.11 & 205.62 & 56.86 & 4.93 & 34.35 & 17.62 & 2.97 & 3.56 & 32.52 \\
\hline Silver Mulch & 14.90 & 146.37 & 223.97 & 58.58 & 4.57 & 36.45 & 17.68 & 3.23 & 3.61 & 34.37 \\
\hline Red Mulch & 13.43 & 131.61 & 189.00 & 51.34 & 4.63 & 32.13 & 16.57 & 2.73 & 3.35 & 29.37 \\
\hline Blue Mulch & 12.83 & 119.48 & 188.67 & 48.16 & 5.20 & 30.12 & 15.08 & 2.46 & 3.05 & 28.26 \\
\hline Yellow Mulch & 11.00 & 122.03 & 177.23 & 48.07 & 5.31 & 31.90 & 16.19 & 2.45 & 3.04 & 25.30 \\
\hline SEM + & 0.590 & 1.79 & 2.77 & 0.70 & 0.297 & 0.45 & 0.770 & 0.121 & 0.132 & 0.39 \\
\hline C.D. at $5 \%$ & 1.82 & 5.30 & 8.24 & 2.07 & NS & 1.33 & NS & 0.37 & 0.40 & 1.15 \\
\hline $\mathrm{CV}$ & 8.74 & 7.54 & 7.62 & 7.37 & 10.01 & 7.45 & 8.33 & 8.18 & 7.23 & 7.37 \\
\hline
\end{tabular}


Table.2 Effect of different mulching materials on fruit quality of watermelon cv. Sugar baby

\begin{tabular}{|c|c|c|c|c|c|c|c|c|}
\hline Treatment & $\begin{array}{l}\text { Fruit pulp wt } \\
\qquad(\mathrm{kg})\end{array}$ & TSS (\%) & $\begin{array}{c}\text { Acidity } \\
(\%)\end{array}$ & $\begin{array}{l}\text { Reducing } \\
\text { sugar (\%) }\end{array}$ & NR (\%) & $\begin{array}{l}\text { Total } \\
\text { Sugar }\end{array}$ & $\begin{array}{l}\text { Av Soil } \\
\text { Temp. }\end{array}$ & $\begin{array}{c}\text { Mositure } \\
(\%)\end{array}$ \\
\hline Control & 1983.33 & 10.07 & 0.44 & 1.27 & 2.90 & 4.17 & 33.70 & 47.50 \\
\hline Wheat Straw & 2101.33 & 10.20 & 0.41 & 1.53 & 3.20 & 4.73 & 31.60 & 46.30 \\
\hline Grasses & 2065.33 & 10.24 & 0.40 & 1.57 & 3.31 & 4.88 & 32.10 & 44.70 \\
\hline Black Mulch & 2308.67 & 10.24 & 0.37 & 1.76 & 3.61 & 5.37 & 31.70 & 46.80 \\
\hline Silver Mulch & 2418.67 & 10.43 & 0.36 & 1.80 & 3.67 & 5.47 & 30.90 & 48.10 \\
\hline Red Mulch & 2185.00 & 10.18 & 0.41 & 1.63 & 3.56 & 5.19 & 31.60 & 46.00 \\
\hline Blue Mulch & 2148.67 & 10.24 & 0.38 & 1.59 & 3.19 & 4.78 & 32.20 & 47.20 \\
\hline Yellow Mulch & 2115.00 & 10.27 & 0.40 & 1.60 & 3.50 & 5.10 & 32.20 & 45.00 \\
\hline SEM + & 31.47 & 0.378 & 0.017 & 0.099 & 0.158 & 0.07 & - & - \\
\hline C.D. at $5 \%$ & 93.49 & NS & 0.05 & 0.30 & 0.48 & 0.22 & - & - \\
\hline $\mathrm{CV}$ & 7.55 & 6.40 & 7.22 & 10.77 & 8.61 & 7.61 & - & - \\
\hline
\end{tabular}


Table.3 Effect of different mulching material on economics of water melon cv. Sugar baby

\begin{tabular}{|c|c|c|c|c|c|c|}
\hline Treatment & Yield (t/ha) & $\begin{array}{c}\text { Gross realization } \\
\text { (Rs/ha) }\end{array}$ & $\begin{array}{c}\text { Total Expenditure } \\
\text { (Rs/ha) }\end{array}$ & $\begin{array}{l}\text { Net realization } \\
\text { (Rs/ha) }\end{array}$ & CBA & CBA \\
\hline Control & 21.59 & 215900 & 199770 & 16130 & 0.075 & 1.08 \\
\hline Wheat Straw & 24.37 & 243700 & 200120 & 43580 & 0.179 & 1.22 \\
\hline Grasses & 24.56 & 245600 & 199790 & 45810 & 0.187 & 1.23 \\
\hline Black Mulch & 32.52 & 325200 & 204480 & 120720 & 0.371 & 1.59 \\
\hline Silver Mulch & 34.37 & 343700 & 204480 & 139220 & 0.405 & 1.68 \\
\hline Red Mulch & 29.37 & 293700 & 204480 & 89220 & 0.304 & 1.44 \\
\hline Blue Mulch & 28.36 & 282600 & 204480 & 78120 & 0.276 & 1.38 \\
\hline Yellow Mulch & 25.30 & 253000 & 204480 & 48520 & 0.192 & 1.24 \\
\hline SEm \pm & & & & 1111 & 0.004 & 0.02 \\
\hline CD at $5 \%$ & & & & 3301 & 0.011 & 0.06 \\
\hline CV & & & & 8 & 7.767 & 7.44 \\
\hline
\end{tabular}




\section{Effect on quality}

The data indicated that the effect of various treatments of mulching material on quality parameters viz. total soluble solid, fruit pulp weight $(\mathrm{g})$, acidity $(\%)$, reducing sugar, total sugars and non-reducing sugar was found significant in fruit of watermelon. It was found that all treatments of mulching material were significantly increased the fruit pulp weight of watermelon but it was unable to exert significant influence on number of seeds per fruit than control. Among all treatments of mulching, maximum fruit pulp weight was recorded in treatment silver mulch. An increase in fruit pulp weight in mulched plants may further attributed to the reason that plants remain physiologically more active to build up sufficient food stock for the developing fruits. The above result were in agreement with those of Suresh and Ashok Kumar (2006) in pointed gourd, Angrej -Ali and Gaur (2007) in strawberry, Aruna and Roy (2005) in water melon.

It was found that application of mulching material had produced a significant effect on acidity percent in fruit of watermelon than control. Among all treatments of mulching, maximum fruit pulp weight was recorded in treatment silver mulch. An increase in fruit pulp weight in mulched plants may further attributed to the reason that plants remain physiologically more active to build up sufficient food stock for the developing fruits. The above result were in agreement with those of Suresh and Ashok Kumar (2006) in pointed gourd, Angrej-Ali and Gaur (2007) in strawberry, Aruna and Roy (2005) in water melon.

It was found that application of mulching material had produced a significant effect on acidity per cent in fruit of watermelon than control. Among all the treatments of mulching significantly minimum acidity were observed in treatment silver mulch over control. The present findings were in accordance with Sharma and Agarwal, Narendra (2004) and Aruna (2007) in tomato. The total soluble solids (\%), reducing sugar (\%), total sugars $(\%)$ and non-reducing sugar (\%) were significantly increased that the control. Among all treatments of mulching, maximum TSS, reducing sugars, total sugar and nonreducing sugar of water melon were observed in treatment silver mulch. While, the minimum sugar content of watermelon fruit was observed in control treatment. The present findings were in close confirmation with Ansary and Roy (2005) in watermelon, Sharma and Agarwal, Narendra (2004) and Aruna et al., (2007) in tomato.

It was observed from Table 3 that highest net return with maximum CBR was obtained with treatment silver mulch followed by black mulch. The lowest net return with minimum CBR was obtained in control (no mulch). The net realization was increased due to different mulches as compared to control treatment. The treatment of silver mulch recorded higher fruit yield through higher net realization. These findings are in close agreement with the results of Singh et al., (2006) in cabbage, Suresh and Ashok Kumar (2006) in pointed gourd and Balraj Sing et al., (2007) in bitter gourd.

It is concluded that application of mulches over control is beneficial to farmers. Higher the CBR, needs to be adopted first by farmers based on availability of mulch material and other priority criteria.

\section{References}

AlemayehuAmbaye and Joseph P.A. (2002). Influence of drip irrigation and mulching on soil moisture retention, water use efficiency, growth and yield of oriental pickling melon (Cucumis 
meloL. var. conomanmakino) South Indian Hort., 50(4/6): 421-429.

Al-Majali, M.A. and Kasrawi, M.A. (1995). Plastic mulch use and method of planting influences on rainfed muskmelon production. Pure and Applied Sci., 22(4): 1039-1054.

Andino, J.R. and Motsenbocker, C.E.(1998). Coloured plastic mulches influences on cucumber beetle populations, vine growth and yield of watermelon. Hort. Sci., 39(6):1246-1249.

Angrej Ali and Gaur, G.S. (2007), Effect of mulching on growth, fruit yield and quality of strawberry. (Fragaria $\mathrm{x}$ ananassa Duch.) Asian J. Hort. 2(1): 149-151.

Ansary, S.H. and Roy, D.C.(2005). Effect of irrigation and mulching on growth, yield and quality of watermelon (Citrullus lonatus Thumb.) Environment and Ecology., 23 (spl-1):141-143.

Arancibia, R.A. and Motsenbocker, C.E. (2008). Differential watermelon fruit size distribution in response to plastic mulch and spun bonded polyester row cover. Hort. Tech., 18(1): 45-52.

Aruna, P., Sudagar, I.P., Manivannan, M.L., Rajangam, J. and Natarajan S. (2007). Effect of fertigation and mulching for yield and quality in tomato cv. PKM-1, Asian J. Hort., 2(2): 50-54.

Balraj, Singh; MaheshKumar and Mehta, S.P. (2007). Advancing bitter ground crop by plastic mulching a profitable and sustainable technology for peri-Urban areas of Northern India. Acta. Hort., 731:199-201.

Battikhi, A.M. and Ghawi, I. (1987). Muskmelon production under mulch and trickle irrigation in the Jordan valley. Hort. Sci., 22(4):578-581.

Bhella, H.S. (1988). Effect of trickle irrigation and black mulch on growth yield and mineral composition of watermelon. Hort. Sci, 223(1):123-125.
Brinen, G.H. and Locascio, D.J. (1979). Plant and row spacing, mulch and fertilizer rate effect on watermelon production. Amer-Hort. Sci., 104(6):724-726.

Cenobio Pedro, G., Inzunzalbarna, M.A., Mendozn Moreno, S.F., Sanchez Cohen, I., and Roman Lopez A. (2007). Response of watermelon to colored plastic mulches under drip irrigation. Terra, 24(4) : 515-520.

Dean, Ban; Zanic, K; Dumicic, G; Culjak, T.G. and Ban, S.G. (2004). The type of polythene mulch impact on vegetable growth, yield and aphid population in watermelon production. J. food Agri. and Envi. 7(3-4): 543-550.

Hallidri, M (2001). Comparison of the different mulching materials on the growth, yield and quality of cucumber. (Cucumis sativus L.) Acta. Hort., 559: 49-54.

Hanna, H.Y. (2000). Black Polyethylene mulch does not reduce yield of cucumbers, double cropped with tomatoes under heat stress. Hort. Sci., 35(2): 190-191.

Ibarra Limenez, L; Zermeno Gonzalez,A; Munguia Lopez, J., Quezada Martin, M.A.R. and Rosa Ibarra, M. deLa.(2008). Photosynthesis, soil temperature and yield of cucumber as affected by colored plastic mulch. Acta Agriculture Scandinavica Section B. Plant Soil Science 58(4): 372-378.

Ibarra, L., Flores, J. and Diaz Perez, J.C. (2001). Growth and response to plastic mulch and row cover. Scientia Horticulturae, 87(1/2): 139-145.

Johnson, J.M., Hough Goldstein, J.A. and Vangessel, M.J. (2000). Effect of straw mulch on Pest insect, Predators and weeds in watermelon and Potatoes. Environmental Entomology, 33:16321643.

Messiaen, C.M. 1992. The tropical vegetables garden, Macmillan presse 
Ltd., London and Basingstoke in cooperation with CTA. The Netherlands, 514 pp.

Panse, V.G. and Sukhatme, P.V. (1985). "Statistical methods for agricultural workers" $4^{\text {th }}$ Edition. Indian Council of Agricultural Research. 87-89.

Rudivch, J; Elassar, G and Shefi, Y. (1978). Optional growth stages for the application of drip irrigation to muskmelon and watermelon. J. Hort. Sci. 53(1): 11-15.

Sharma, H.G. and Agarwal, Narendra (2004). Effect of different colour mulches on the growth and yield of tomato under drip irrigation. Plant Archives 4(1): 9399.

Singh, V.P., Singh, R.P. and Arora, S.K., Godara, A.K., Yadav, B.S. (2006). Effect of black polythene mulch on growth and fruit yield of tomato.
Haryana J. Hort. Sci., 35 (3/4): 323.

Siwek, P.andKunicki(1998). Ecological aspects of mulching with polythene film in early cucumber cultivation. Roczniki Akademii Rolniczej-w-Poznaniu, Orgrodnictwa, 27: 277-283.

Splittsloesser, W.E. (1990). Vegetables growing handbook organic and traditional methods. Plant Physiology in Horticulture, University of Issionis, Urban Illionis pp-113-115.

Suresh, R. and Ashok, Kumar (2006). Effect of drip irrigation and mulch on pointed gourd in calcareous soil of North Bihar. Indian. J. Soil Cons. 34 (1): 83-86.

White, JM (2002). Pumpkin yield and size when grown on for plastic mulches as a second crop. Proc. Fla State Hort. Sci. $115: 232-233$.

\section{How to cite this article:}

Dadheech, S., Ramawtar and Yadav, C.M. 2018. Impact of Mulching Material on the Growth, Yield and Quality of Watermelon (Citrullus lonatus). Int.J.Curr.Microbiol.App.Sci. 7(07): 2774-2782. doi: https://doi.org/10.20546/ijcmas.2018.707.324 